\title{
PTCH1 Gene
}

National Cancer Institute

\section{Source}

National Cancer Institute. PTCH1 Gene. NCI Thesaurus. Code C18255.

This gene is involved in tumor suppression and mutations in this gene have been associated with several cancers and cancer related diseases. 